\title{
Group-based food and nutritional education for the treatment of obesity in adult women using the family health strategy
}

\author{
Educação alimentar e nutricional em grupo para \\ o tratamento do excesso de peso em mulheres \\ adultas na estratégia de saúde da família
}

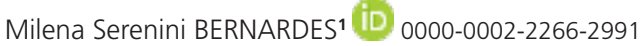

Letícia MARÍN-LÉON² (D) 0000-0002-2558-1951

\section{A B S T R A C T}

\section{Objective}

The high prevalence of obesity and its association with chronic diseases is a major public health problem. This study aimed to evaluate a group-based Food and Nutrition Education Program for the treatment of excess weight in Brazilian women attending the Family Health Strategy.

\section{Methods}

This quasi-experimental intervention study was conducted among 172 women, including 87 women in the intervention group who participated in a nutritional education program that addressed topics in the area of nutrition. The Intervention and Control groups underwent an anthropometric evaluation at the beginning of the study and at the 6th month.

\footnotetext{
1 Prefeitura Municipal de Poços de Caldas, Secretaria Municipal de Saúde, Núcleo de Apoio à Saúde da Família. R. Pará, 284, Centro, 37701-026, Poços de Caldas, MG, Brasil. Correspondência para/Correspondence to: MS BERNARDES. E-mail: <miserenini@gmail.com>

2 Universidade Estadual de Campinas, Faculdade de Ciências Médicas, Departamento de Saúde Coletiva. Campinas, SP, Brasil.

Article based on the máster thesis of MS BERNARDES, entitled "Atendimento nutricional coletivo como estratégia de ação para o tratamento do excesso de peso em mulheres adultas na estratégia de saúde da família em Poços de Caldas (MG)". Universidade Estadual de Campinas; 2016.
}

Como citar este artigo/How to cite this article

Bernardes MS, Marín-Léon L. Group-based food and nutritional education for the treatment of obesity in adult women using the family health strategy. Rev Nutr. 2018;31(1):59-70. https://doi.org/10.1590/1678-98652018000100006 


\section{Results}

At the end of the intervention, the intervention group showed a significant reduction in weight and Body Mass Index, while the control group showed an increase in these variables. Women who completed the intervention $(n=71)$ showed a mean difference of $-5.15 \mathrm{~kg}$ and a reduction of 2.04 points in the Body Mass Index. Still $50.7 \%$ of the participants in the intervention group achieved a weight loss greater than or equal to $5.0 \%$, and $40.8 \%$ of them maintained this reduced weight for up to seven months after the end of the intervention.

\section{Conclusion}

This study emphasizes the importance of group-based food and nutritional education interventions to promote and maintain weight loss, and thus, prevent and treat chronic diseases.

Keywords: Clinical trial. Family health. Food and nutrition education. Nutritional surveillance. Obesity.

\section{RE S U M O}

\section{Objetivo}

Este estudo tem como objetivo avaliar um programa de Educação Alimentar e Nutricional em grupo para o tratamento do excesso de peso em mulheres brasileiras usuárias da Estratégia de Saúde da Familia.

\section{Métodos}

Trata-se de um estudo de intervenção quase-experimental realizado com 172 mulheres. Dentre elas, aquelas que faziam parte do grupo intervenção $(n=87)$ participaram de um programa de educação alimentar que abordou temas da área de alimentação e nutrição. Tanto o grupo intervenção quanto o de controle passaram por avaliação antropométrica no início e no sexto mês do programa.

\section{Resultados}

Foi observada perda de peso significativamente superior no grupo intervenção: ao final do período, observou-se redução do peso e do índice de massa corporal no primeiro grupo, em contraste com aumento no grupo controle. Entre as mulheres que finalizaram a intervenção $(n=71)$ foi observada diferença média de $-5,15 \mathrm{Kg}$, e redução de 2,04 pontos do Índice de Massa Corporal inicial. Ainda 50,7\% das participantes do grupo intervenção atingiram uma redução de peso $\geq 5,0 \%$, sendo que houve manutenção dessa redução em $40,8 \%$, sete meses após o termo da intervenção.

\section{Conclusão}

O estudo evidencia a importância da Educação Alimentar e Nutricional em grupo para estimular e manter a perda de peso, e assim prevenir e tratar doenças crônicas.

Palavras-chave: Ensaio clínico. Saúde da família. Educação alimentar e nutricional. Vigilância nutricional. Obesidade.

\section{NTRODUCTIO N}

Currently, the high prevalence of obesity and its association with Chronic, Noncommunicable Diseases (CND) is a major public health concern $[1,2]$. In 2014, the percentage of overweight Brazilian women aged 18 years or older reached $47.4 \%$ [3]. The modernization and industrialization in the last few decades have resulted in an increase in caloric intake and a decrease in physical activity in women, contributing to the accumulation of fat and obesity [4]. This period was also characterized by the transition from high rates of malnutrition to high rates of obesity, and Brazil showed an increase in the prevalence of obesity even among the poorest population [5]. From 1970 to 2009, the Brazilian food consumption pattern was marked by an increased intake of ultra-processed foods, stagnated consumption of fruits and vegetables (with values lower than those recommended), and decreased consumption of staple foods, including fish, eggs, legumes, roots, tubers, and rice [6]. The consumption of foods rich in saturated and trans-fats, sugar, and salt increased, while the consumption of fiber and 
complex carbohydrates decreased [6]. Low dietary fiber consumption increases the risk of diabetes, obesity, cardiovascular diseases, and some types of cancer, including colon and rectal cancer [7]. Diets with high energy density impair the physiological control of energy balance, increasing the risk of weight gain [8].

The prevention and control of CND and their modifiable risk factors, such as tobacco smoking, physical inactivity, unhealthy eating, and comorbidities, including obesity, are among the objectives of the Plano de Enfrentamento das CND, which includes preventive and health promotion initiatives, combined with early detection and proper treatment, focusing on primary care and community involvement $[9,10]$. However, in addition to individual treatment, the control of CND primarily requires the implementation of public policies [10]. Health services seek to develop healthcare strategies to improve the quality of life and decrease health complications and early deaths [11]. Among its principles, the Family Health Strategy (FHS) enables us to increase health awareness, the knowledge of rights and duties, and the autonomy of individuals in treating morbidities [12].

Food and Nutrition Education (FNE) in groups is a health education strategy to promote changes in an individual's eating habits to stimulate autonomy and critical thinking regarding their health $[10,13,14]$. In Brazil, a group approach with different objectives, primarily based on social sciences and psychology, has been widely used as a healthcare strategy since 1970 [15]. Patient groups, including those with hypertension, diabetes, and obesity, are usually formed within primary healthcare units. Food and Nutrition Education is crucial for health groups because it advocates the use of problembased and active education resources, which promote dialogue or an exchange of knowledge and practices between the participants and the healthcare professionals with technical and scientific knowledge [16]. FHS considers all issues related to food behavior, such as culture, health status, marketing, and socioeconomic status [16]. A challenge that these programs are facing is the adherence to habits acquired during the intervention period [17], which may be strengthened by the FHS through enhanced critical thinking, self-esteem, and resilience [16]. This study aimed to assess the treatment of obesity as a part of the FHS, using Food and Nutrition Education groups.

\section{METHODS}

This was a quasi-experimental, prospective, and comparative, study of overweight or obese women, with before and after intervention analysis. The women were attended in four family health teams of the municipality of Poços de Caldas (MG). The study included 172 overweight/obese adult women who were referred for a nutrition consultation. Of these women, 87 were in the Intervention Group (IG) (consisting of women interested in joining the Food and Nutrition Education group "Vida Leve" [Light Life]) and 85 were in the Control Group (CG) (who were not interested in receiving the intervention). Each meeting was attended by a maximum of 20 women and lasted for 60 minutes. Pregnant women and those younger than 20 years were excluded from the study. The goal of the "Vida Leve" group was to promote weight loss and was managed by a nutritionist, who was solely responsible for conducting all meetings and collecting the data. Men were excluded from the study since fewer obese men were referred to the nutrition team.

All participants filled out a questionnaire with closed-ended and pre-categorized questions on demographic characteristics, socioeconomic conditions, health status, and frequency of food consumption. Most of the questions related to sociodemographic aspects were based on the Pesquisa Nacional por Amostra de Domicílios (PNAD, National Household Sample Survey) [18]. Food intake was estimated using an adapted 
food frequency questionnaire [19], organized into 11 groups: milk and dairy products, meat, eggs and derivatives, cereals and derivatives, vegetables, fruits, legumes, roots and tubers, oils and fats, sugars and sweets, fried foods and sandwiches, and beverages. The frequency of intake was categorized as never, non-daily consumption, and daily consumption.

Anthropometric evaluation was conducted by measuring the patient's weight and height using a digital electronic scale and stadiometer, respectively. The Body Mass Index (BMI) was calculated by dividing the body weight (in $\mathrm{kg}$ ) by squared height (in meters) $\left(\mathrm{W} / \mathrm{H}^{2}\right)$. The $\mathrm{BMI}$ classification recommended by the World Health Organization [20], which defines overweight as $\mathrm{BMI} \geq 25.0$ and $<30 \mathrm{~kg} / \mathrm{m}^{2}$ and obese as BMI $\geq 30.0 \mathrm{~kg} / \mathrm{m}^{2}$, was used for the non-elderly women. The following cut-off points recommended by the Pan American Health Organization [20] were used for the elderly women: $\mathrm{BMI} \geq 28$ and $<30 \mathrm{~kg} / \mathrm{m}^{2}$ for pre-obesity and $\mathrm{BMl} \geq 30 \mathrm{~kg} / \mathrm{m}^{2}$ ) for obesity.

The participants of the IG received an individualized diet plan, prescribed after analyzing the 3-day food record, including one weekend. This diet plan was prepared according to the recommendations of the Global Strategy on Diet, Physical Activity and Health - World Health Organization (DPASMHO) [21], which advocates emphasis on energy restriction from fats, exclusion of trans-fats, minimum daily consumption of $400 \mathrm{~g}$ of fruits and vegetables, limited consumption of free sugar and salt, and increased intake of foods rich in fiber. The educational intervention consisted of 7 monthly meetings that last, on an average, 60 minutes. Food and nutritional issues were discussed in the meeting (Chart 1), and details of the meeting were published in an information leaflet. The

Chart 1.Description of meetings and methods used in the food and nutrition education group Vida Leve. Poços de Caldas (MG), Brazil, 2015

\begin{tabular}{|c|c|c|c|}
\hline Theme of the meeting & Objectives & Instrument & Techniques \\
\hline Food groups and servings & $\begin{array}{l}\text { To enable the participants to replace foods and } \\
\text { diversify the diet within the quantities proposed } \\
\text { in the diet plan. }\end{array}$ & Photographic album & Circles of conversation \\
\hline Labeling & $\begin{array}{l}\text { To teach the participants to interpret food labels } \\
\text { and to choose the healthiest products with the } \\
\text { best cost/benefit ratio. }\end{array}$ & Food labels & Circles of conversation \\
\hline Fibers & $\begin{array}{l}\text { To explain the importance of fibrous diet, their } \\
\text { role in controlling satiety, and simple strategies } \\
\text { to increase the daily intake of fiber. }\end{array}$ & Lecture & $\begin{array}{l}\text { Balloon sentence } \\
\text { dynamic }\end{array}$ \\
\hline $\begin{array}{l}\text { Cooking methods and food } \\
\text { hygiene }\end{array}$ & $\begin{array}{l}\text { To teach participants how to (a) prepare food } \\
\text { with less oil and salt, (b) make better use of the } \\
\text { nutrients in each food, and (c) implement food } \\
\text { hygiene and preservation methods. }\end{array}$ & $\begin{array}{l}\text { Lecture + information } \\
\text { folders }\end{array}$ & Circles of conversation \\
\hline Obesity in Brazil & $\begin{array}{l}\text { To discuss the problems of obesity in Brazil and } \\
\text { its health impacts. }\end{array}$ & $\begin{array}{l}\text { Documentary Muito } \\
\text { Além do Peso [far } \\
\text { beyond weight] }\end{array}$ & $\begin{array}{l}\text { Circles of conversation } \\
\text { and preparation of a } \\
\text { mural }\end{array}$ \\
\hline Dietary workshop & $\begin{array}{l}\text { To teach participants to adapt traditional recipes } \\
\text { and make them healthier. }\end{array}$ & Case study and Q\&A & Circles of conversation \\
\hline $\begin{array}{l}\text { Nutritional treatment and } \\
\text { motivation }\end{array}$ & $\begin{array}{l}\text { To report the reasons for each participant to seek } \\
\text { and to remain in the group and what were their } \\
\text { perceptions and perspectives after the group } \\
\text { ended. }\end{array}$ & Questionnaire & Circles of conversation \\
\hline
\end{tabular}

Note: Q\&A: Questions and Answers. 
topics discussed in the meetings were chosen based on the profile of the participants (initial interview), considering the principles of healthy eating and the guidelines of the Primary Care Notebooks [13].

Anthropometric measurements of the IG members were performed every other month (2nd, 4th, and 6th month). A new anthropometric measurement was performed 7 months after completion of the intervention (13 months after the study initiation), to assess if the outcomes remained similar to those at the 6th month.

The 85 women in the CG were subjected to an initial interview, an anthropometric and dietary evaluation at the beginning of the study, and a new anthropometric measurement at the 6th month. The individuals from the CG did not receive any nutritional care during the study period. These individuals were not at risk and had no serious health problems associated with overweight and continued to wait for individual care, as defined by the municipal protocol for nutritional care.

An electronic form was created using Google Forms. The Excel spreadsheet generated was subsequently exported to Statistical Package for the Social Sciences 18.0 (SPSS) (SPSS Inc., Chicago, Illinois, United States of America) for data analysis. The exploratory analysis included simple and relative frequencies of the categorical variables. To compare the ratios of the independent variables between the control and the intervention groups, Pearson's chi-squared test, Fisher's exact test, and Fisher's exact test generalization were used, when necessary, with a $5 \%$ significance level. Residual analysis was used in independent variables, with three or more categories having significant differences between intervention and control groups.

The continuous variables were described by calculating the mean, median, minimum, and maximum values; interquartile range (P25;P75); and standard deviation. The normality of their distribution was assessed using the KolmogorovSmirnov test. To assess the differences between the control and intervention groups, the T test for independent samples was used to compare the mean differences between Final and Initial BMI (BMIf-BMli) and the mean absolute differences between Final and Initial Weight (WfinalWinitial). The Mann-Whitney $U$ Test was used to compare the proportional weight difference ((final weight-initial weight)/initial weight $\times$ 100 ) between the $C G$ and the IG because this variable does not show a normal distribution. Furthermore, in the IG, the weight at the 2nd, 4th, and 6th month was compared with the initial weight using the paired sample t-test. The ratio of "at least $5 \%$ weight loss" over the initial weight was also calculated, for each period of anthropometric measurements.

The research study was approved by the Municipal Health Secretariat of Poços de Caldas (MG) - and by the Research Ethics Committee of the Universidade Estadual de Campinas (Unicamp, University of Campinas; statement $n^{\circ}$ 888.940 of November 27, 2014). All participants signed an informed consent before joining the study.

\section{RE S U L T S}

The participants in the IG were aged 20 to 70 years (mean \pm SD: $46.6 \pm 13.0$ ), while those in the CG were aged 47.6 years $( \pm 13.3)$. The IG predominantly consisted of individuals that were white or yellow self-referred color $(p=0.018)$. Participants in both groups were mostly married and no significant differences were found in their education level or economic status. All study participants lived in brick houses and had access to drinking water from the water supply network, to public sewage system, and garbage collection (data not shown in Tables).

Answers to a questionnaire administered before the intervention showed that most participants described their health as very good or good, never smoked, did not exercise at home, and did not participate in the neighborhood exercise group. There were no significant differences in 
the prevalence rates of hypercholesterolemia, arterial hypertension, depression, and diabetes between the groups, but significant differences in dietary restrictions related to high cholesterol and self-referred overweight were identified (Table 1).

At the beginning of the study, no significant differences in the consumption of

Table 1. Characteristics of the health status of the adult women included in the intervention and control groups ${ }^{1}$. Poços de Caldas (MG), Brazil, 2014-2015.

\begin{tabular}{|c|c|c|c|}
\hline Variables & Intervention group $(\mathbf{n}=\mathbf{8 7}) \%$ & Control group $(n=85) \%$ & $p$-value* \\
\hline Perceived health status & & & 0.666 \\
\hline Very good or good & 70.0 & 67.0 & \\
\hline Normal or poor & 30.0 & 33.0 & \\
\hline Tobacco smoking & & & 0.157 \\
\hline Never smoked & 84.0 & 71.7 & \\
\hline Former smoker & 10.3 & 18.8 & \\
\hline Smoker & 05.7 & 9.5 & \\
\hline Participates in the neighborhood exercise group & & & 0.261 \\
\hline Yes & 30.0 & 22.3 & \\
\hline No & 70.0 & 77.7 & \\
\hline Exercises at home & & & 0.396 \\
\hline Yes & 24.0 & 18.8 & \\
\hline No & 76.0 & 81.2 & \\
\hline Considers herself overweight & & & 0.033 \\
\hline Yes & 98.8 & 91.8 & \\
\hline No & 1.2 & 8.2 & \\
\hline Hypertension & & & 0.364 \\
\hline Yes & 33.3 & 40.0 & \\
\hline No & 66.7 & 60.0 & \\
\hline High cholesterol levels & & & 0.895 \\
\hline Yes & 39.0 & 38.7 & \\
\hline No & 61.0 & 61.3 & \\
\hline Dietary restrictions due to high cholesterol & & & $0.001^{* *}$ \\
\hline Yes & 67.8 & 41.3 & \\
\hline No & 32.2 & 58.7 & \\
\hline Depression & & & 0.400 \\
\hline Yes & 17.3 & 22.3 & \\
\hline No & 82.7 & 77.7 & \\
\hline Diabetes & & & 0.627 \\
\hline Yes & 12.6 & 14.0 & \\
\hline No & 87.4 & 86.0 & \\
\hline
\end{tabular}


various foods studied were observed between the groups, except for margarine, which showed a higher daily intake in the IG $(p<0.05)$ (data not shown in Tables).

In this study, 16 participants dropped out of the IG, at different periods. The participants of the control, intervention, and drop out groups had a mean height of $1.58 \mathrm{~m}$. The initial weight of the participants in the IG was higher than that of the participants in the CG and lower than that of the participants in the dropout group. The mean, but not the median, final weight of the participants was highest in the dropout group followed by the $C G$ and then IG. The mean initial $\mathrm{BMI}$ of the IG was higher than that of the CG and lower than that of the dropout group. The final BMI of the IG and CG were equal and lower than that of the dropout group. However, there was an interquartile overlap in the differences of all measures between groups (Table 2).

The mean differences in the final weight and BMI and their respective initial values indicated a significant reduction in both weight and $\mathrm{BMI}$ in the IG. The CG showed a slight increase in BMI. These differences were observed in all women who were treated for obesity (group $A, n=87$ ), those who attended all sessions (group $B, n=62$ ), and those who missed only one session (group $C, n=71$ ). The differences were higher in group $B$ and intermediate in group C. At the end of the intervention period (6th month), the mean weight loss in group $C$ was $-4.74 \mathrm{~kg}$ (Table 3).

Figure 1 shows the pattern of weight loss in women in the different subgroups within the IG, those who were treated for obesity $(n=87)$,

Table 2. Analysis of the anthropometric variables of the control $(n=85)$, intervention $(n=71)^{*}$, and dropout $(n=16)^{* *}$ groups of the food and nutrition education program Vida Leve. Poços de Caldas (MG), Brazil, 2014-2015.

\begin{tabular}{|c|c|c|c|c|c|c|}
\hline Variables & Mean & SD & Median & Minimum & Maximum & IQR P25-P75 \\
\hline \multicolumn{7}{|l|}{ Height (m) } \\
\hline Control & 1.58 & 5.82 & 1.59 & 1.45 & 1.72 & $1.55-1.63$ \\
\hline Intervention & 1.58 & 6.58 & 1.59 & 1.36 & 1.73 & $1.55-1.63$ \\
\hline Dropout & 1.58 & 8.25 & 1.58 & 1.45 & 1.70 & $1.48-1.64$ \\
\hline \multicolumn{7}{|l|}{ Initial Weight } \\
\hline Control & 80.62 & 15.61 & 77.00 & 58.00 & 130.00 & $70.00-88.85$ \\
\hline Intervention & 84.09 & 16.37 & 83.30 & 48.60 & 147.70 & $73.30-92.00$ \\
\hline Dropout & 85.17 & 17.21 & 85.75 & 61.80 & 121.60 & $68.40-95.65$ \\
\hline \multicolumn{7}{|l|}{ Final Weight } \\
\hline Control & 81.02 & 15.42 & 77.00 & 58.00 & 134.00 & $71.10-88.65$ \\
\hline Intervention & 79.34 & 15.80 & 78.60 & 47.00 & 142.00 & $68.00-86.90$ \\
\hline Dropout & 83.09 & 16.93 & 83.55 & 60.00 & 119.00 & $67.30-94.78$ \\
\hline \multicolumn{7}{|l|}{ Initial BMI } \\
\hline Control & 31.89 & 5.43 & 30.58 & 25.30 & 49.60 & $27.68-34.29$ \\
\hline Intervention & 33.40 & 5.98 & 31.79 & 25.70 & 55.6 & $28.81-36.45$ \\
\hline Dropout & 34.21 & 6.02 & 32.64 & 28.20 & 47.40 & $29.65-35.57$ \\
\hline \multicolumn{7}{|l|}{ Final BMI } \\
\hline Control & 32.04 & 5.30 & 30.67 & 24.43 & 48.83 & 28.13-33.94 \\
\hline Intervention & 32.02 & 6.15 & 30.80 & 22.59 & 56.08 & 27.69-33.95 \\
\hline Dropout & 34.29 & 6.36 & 31.93 & 27.12 & 46.02 & $29.45-40.61$ \\
\hline
\end{tabular}

Note: "Women who participated in all sessions of the program Vida Leve and those who missed one session were included; ${ }^{* *}$ All women who missed two or more Vida Leve sessions.

IQR Interquartile Range: from the 25th percentile to the 75th percentile; SD: Standard Deviation; BMI: Body Mass Index. 
Table 3. Analysis of the differences in the Body Weight and initial and final Body Mass Index (BMI) between the intervention* and control groups. Poços de Caldas (MG), Brazil, 2014-2015.

\begin{tabular}{|c|c|c|c|c|c|}
\hline & $\begin{array}{l}\text { Initial/final } \\
\text { number of } \\
\text { subjects }\end{array}$ & $\begin{array}{l}\text { Mean difference } \\
\text { between the initial } \\
\text { and final value }\end{array}$ & $\begin{array}{l}\text { Standard erros } \\
\text { of the mean }\end{array}$ & $\begin{array}{l}\text { Mean difference } \\
\text { between the } \\
\text { intervention and } \\
\text { the control groups }\end{array}$ & $\begin{array}{l}p \text { value of the test of the } \\
\text { difference between } \\
\text { the control and intervention } \\
\text { groups** }\end{array}$ \\
\hline \multicolumn{6}{|l|}{ Weight } \\
\hline Absolute difference & & & & 4.66 & 0.002 \\
\hline Control group & $85 / 85$ & 0.40 & 0.292 & & \\
\hline Intervention group A & $87 / 87$ & -4.25 & 0.403 & & \\
\hline \multicolumn{6}{|l|}{ Weight } \\
\hline Absolute difference & & & & 5.53 & 0.001 \\
\hline Control Group & $85 / 85$ & 0.40 & 0.292 & & \\
\hline Intervention group B & $62 / 62$ & -5.13 & 0.507 & & \\
\hline \multicolumn{6}{|l|}{ Weight } \\
\hline Absolute difference & & & & 5.15 & 0.001 \\
\hline Control group & $85 / 85$ & 0.40 & 0.292 & & \\
\hline Intervention group C & $71 / 71$ & -4.74 & 0.468 & & \\
\hline \multicolumn{6}{|l|}{$B M I$} \\
\hline Absolute difference & & & & 1.85 & 0.001 \\
\hline Control group & $85 / 85$ & 0.15 & 0.114 & & \\
\hline Intervention group A & $87 / 87$ & -1.70 & 0.162 & & \\
\hline \multicolumn{6}{|l|}{$B M I$} \\
\hline Absolute difference & & & & 2.22 & 0.001 \\
\hline Control group & $85 / 85$ & 0.15 & 0.114 & & \\
\hline Intervention group B & $62 / 62$ & -2.07 & 0.203 & & \\
\hline \multicolumn{6}{|l|}{$B M I$} \\
\hline Absolute difference & & & & 2.04 & $<0.001$ \\
\hline Control group & $85 / 85$ & 0.15 & 0.114 & & \\
\hline Intervention group C & $71 / 71$ & -1.89 & 0.188 & & \\
\hline
\end{tabular}

Note: *The intervention group (food and nutrition education group Vida Leve) is subdivided into three subgroups: Group A: participants willing to get treated for obesity, Group B: participants who attended all meetings, and Group C: participants who attended all meetings and those who missed only one session; ${ }^{* *}$ t Test of Independent Samples comparing the mean differences between the final and initial values; BMI: Body Mass Index.

those who attended all sessions and missed only one meeting $(n=71)$, and those who concluded the study without missing any session $(n=62)$. The results showed that the initial weight loss of $5 \%$ or higher in the last group was higher than that in groups with one or more missing sessions in all months. Weight loss of $5 \%$ or higher increased from the first 2 months until the end of the intervention period (6th month). At the 13th month, the ratio of women with $5 \%$ weight loss decreased in relation to the end of the intervention period, though it remained higher than the indicator at the 4th month.

\section{DISCUSSION}

In this study, the participants had an $81.6 \%$ adherence to the intervention. While 62 participants attended all meetings, 9 of them missed one session. The adherence rate reported in this study was higher than that reported in other education intervention studies [22-25]. 


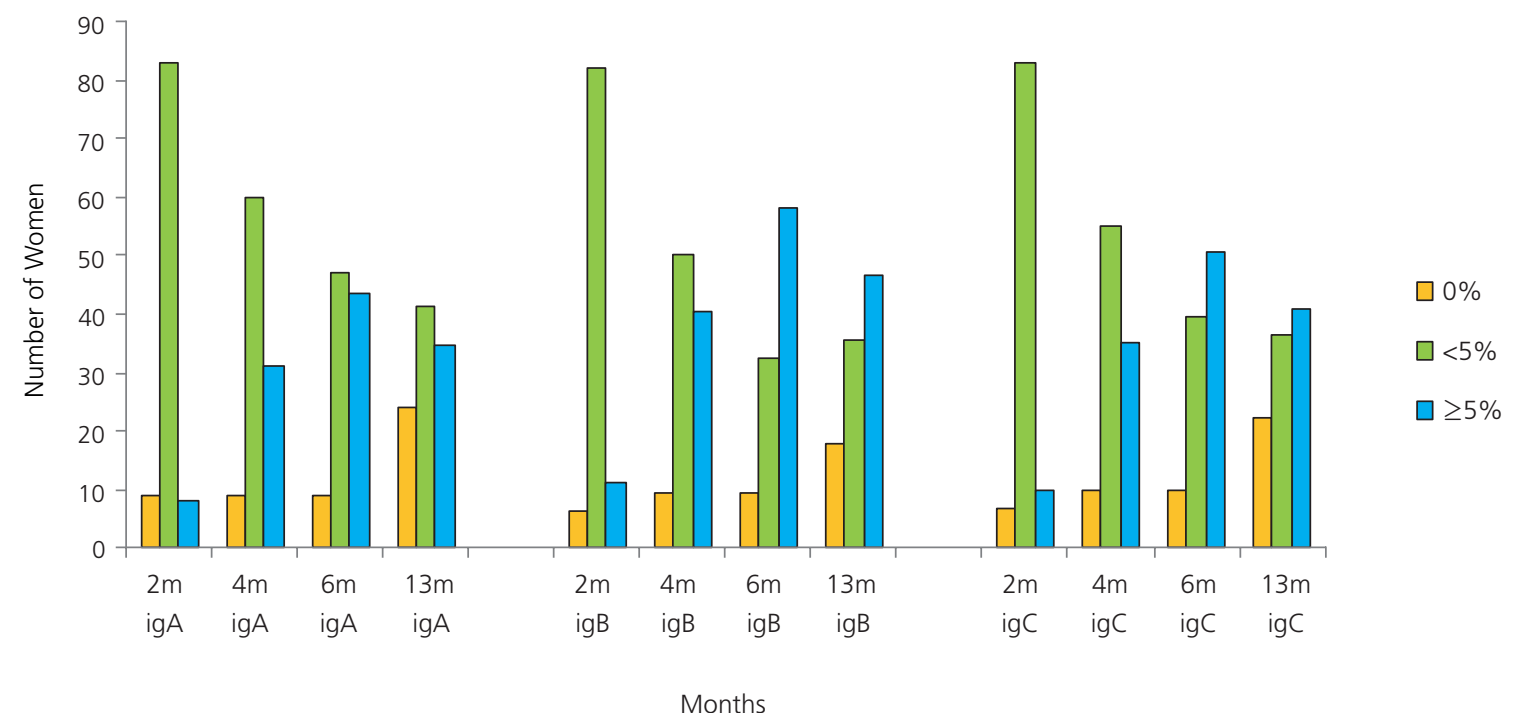

Figure 1. Time course of weight loss in women from the intervention group (food and nutrition education group Vida Leve) according to number of sessions missed. Poços de Caldas (MG), Brazil, 2014-2015.

Note: igA: Women wiling to treat obesity (87); igB: Women who missed no meeting (62); Women who missed only on meeting (71).

The higher adherence rate may be related to the fact that a higher ratio of participants in this group considered themselves overweight and were more careful in avoiding high cholesterol. These behavioral items, although not included in the instrument, termed Readiness Stage for Behavior Change [25], indicate a willingness to change the diet and lose weight, which is less common in studies with random samples.

We agree with Moreira et al. [26], who advocated that a program focused on Food and Nutrition Education for patients who are obese cannot be evaluated only in terms of weight loss or decreased anthropometric measurements, because Food and Nutrition Education affects eating habits mainly by raising awareness of healthy food choices and facilitating healthy eating habits. A Food and Nutrition Education proposal therefore, encourages healthy and adequate eating attitudes, habits, and practices to achieve gradual weight loss. According to Willett et al. [27], support groups help to form values, develop responsibility and critical attitudes. They also help in translating the extensive information on nutrition received into practical strategies for choosing a healthy diet. In São Paulo, a controlled community study showed that the participants with the worst diet at the beginning of the study ended up with improved diet quality [28]. In the final meeting of this study, the participants reported their perceived improvement in diet quality, which also helped the family, according to some of them.

This study showed that both weight loss and reduction in BMl was higher among women who participated in the intervention compared to those in the CG. Other studies reported that weight loss was due to the intervention. In the study by Moreira et al. [26], which involved 40 obese patients, who had to consume a hypocaloric diet and attend meetings that addressed healthy lifestyle habits for 6 months. The authors observed a mean weight loss of $5.9 \%$, which was slightly higher than in our study (5.6\%). A study conducted in Belo Horizonte assessed the impact of a nutritional intervention on the nutritional and anthropometric profile of users of the Programa Academia da Saúde (PAS, Health Academy Program). The intervention 
which lasted for 11 months consisted of Food and Nutrition Education groups and showed a $1.8 \%$ weight loss [29], which was lower than the results of our intervention.

In the Brazilian state capitals, from 2006 to 2013 , the number of overweight and obese individuals has increased in both sexes and in all levels of education [30]. These findings indicate the need for interventions that can reverse this trend, in order to prevent chronic diseases associated with obesity. Support groups have a high potential for bonding and expanding the access to primary healthcare and population coverage. However, public policies covering the various factors that affect the food system such as access to fresh foods, food quality regulation and control, integrated care of overweight individuals, and food and nutritional surveillance, would be strategic in the fight against obesity and must be implemented [31,32].

Some studies show that a $5.0 \%$ weight loss can significantly reduce blood pressure and improve both lipid profile and glucose tolerance. It highlights weight loss as an efficient strategy for prevention and treatment of cardiovascular diseases and diabetes Mellitus [32]. While at the end of our intervention period, $50.7 \%$ of the women achieved a weight loss equal to or higher than $5.0 \%$, a reassessment seven months later showed that this population had decreased to $40.8 \%$. Nevertheless, this decrease indicates that weight loss was maintained, which is one of the educational objectives particularly important for prevention and treatment of chronic diseases.

Individual or collective initiatives geared toward health promotion and disease prevention should be promoted in the context of primary healthcare due to their potential to provide integrated care to overweight users with comorbidities. Nutrition counseling is a simple, low-cost measure with no adverse effects and may be used in primary healthcare settings as a method for prevention and treatment of obesity [33].
Our study has a few limitations. First, is the absence of physical exercises during the intervention period as well as no assessment of food intake at the end of the intervention. These missing parameters make it difficult to compare our findings with those of studies addressing these issues to explain the weight loss. A systematic review conducted by Mendes et al. [34] showed the importance of a multiprofessional approach for obesity treatment. They reported a decrease in anthropometric and biochemical measurements in their studies with adults combining the nutritional approach with a physical activity program.

Another limitation is the use of only one anthropometric indicator to assess the nutritional status of women before and during the intervention. The waist circumference, an indicator used to estimate cardiovascular risk, should have been measured, especially due to its importance in chronic diseases [28]. The lack of funding and shortage of manpower to perform this study compromised the quality of the intervention. Also, the reduced number of anthropometric measurements and the absence of treatment in the CG, represent study limitations. Furthermore, the participants from the IG were those who were willing to receive group Food and Nutrition Education, which may have influenced the higher adherence and therefore, higher weight loss in this group.

Despite these limitations, this study is valuable because (a) the participants showed a high adherence to the intervention, (b) the sample size used was larger than those of several other studies, and (c) it was performed in a primary healthcare setting in the context of the family health strategy, which is usually used by individuals who are at risk of developing chronic diseases and mostly vulnerable population. The assessments before and after the intervention are valid and reflect the actual participation in primary health services. This study was conducted under the usual operational circumstances of the FHS and not by a research team, thus indicating the possibilities of viable intervention in routine primary care. 


\section{CONCLUSION}

The findings of this study may guide groupbased nutritional intervention approaches and the organization of policies and protocols geared towards treating people who are overweight in primary healthcare. The Guia Alimentar para a População Brasileira (GAPB, Dietary Guidelines for the Brazilian Population) should guide the dietary and nutritional recommendation of Food and Nutrition Education activities [35].

Groups focused on Food and Nutrition Education contribute to empowering individuals to make conscious food choices and to develop their autonomy and critical perspective on nutrition by sharing experiences among participants and learning nutrition from experts. The health teams must receive appropriate pedagogical training to develop promotion and prevention initiatives based on popular health education methods and on Food and Nutrition Education, diversifying the conventional healthcare approaches and prioritizing the creation of spaces for dialogue and knowledge exchange. Finally, public policies that improve access to fresh foods at reasonable prices must be widely implemented to ensure that Food and Nutrition Education reaches its individual and population objectives and that the quality of the food industry is regulated and controlled.

\section{CONTRIBUTORS}

Both authors considerably contributed to the study design, data analysis and interpretation, and revision and approval of the final version of this manuscript.

\section{REFERENCES}

1. Hope AA, Kumanyika SK, Shults J, Holmes WC. Changes in health-related quality of life among African-Americans in a lifestyle weight loss program. Qual Life Res. 2010;19(7):1025-33. https://doi.org/10.1007/s11136-010-9669-6

2. World Health Organization. Global health observatory data, 2014. Geneva: WHO; 2015 [cited 2015 Aug 26]. Available from: http://www. who.int/gho/ncd/risk_factors/overweight_text/en/

3. Ministério da Saúde(Brasil). Secretaria de Vigilância em Saúde. Vigitel Brasil 2013: vigilância de fatores de risco e proteção para doenças crônicas por inquérito telefônico. Brasília: Ministério da Saúde; 2014.

4. Tardido AP, Falcão MC. O impacto da modernização na transição nutricional e obesidade. Rev Bras Nutr Clin. 2006;21(2):117-24.

5. Gigante DP, Moura EC, Sardinha LM. Prevalence of overweight and obesity and associated factors, Brazil, 2006. Rev Saúde Pública. 2009;43(2):83-9. https:// doi.org/10.1590/50034-89102009000900011

6. Martins AP, Levy RB, Claro RM, Moubarac JC, Monteiro CA. Increased contribution of ultraprocessed food products in the Brazilian diet (1987-2009). Rev Saúde Pública. 2013;47(4):656-65.

7. Bernaud FS, Rodrigues TC. Fibra alimentar: ingestão adequada e efeitos sobre a saúde do metabolismo. Arq Bras Endocrinol Metab. 2013;57(6):397-405. https://doi.org/10.1590/S0 004-27302013000600001

8. Rolls BJ. The relationship between dietary energy density and energy intake. Physiol Behav. 2009;97(5):609-15. https://doi.org/10.1016/j. physbeh.2009.03.011

9. Ministério da Saúde (Brasil). Secretaria de Atenção à Saúde. A vigilância, o controle e a prevenção das doenças crônicas não-transmissíveis: DCNT no contexto do Sistema Único de Saúde brasileiro/ Brasil. Brasília: Ministério da Saúde; 2005 [acesso 2015 mar 23]. Disponível em: www.saude.es.gov. br/download/GERA_DCNT_NO_SUS.pdf

10. Ministério da Saúde (Brasil). Secretaria de Vigilância em Saúde. Plano de ações estratégicas para o enfrentamento das doenças crônicas não transmissíveis (DCNT) no Brasil 2011-2022. Brasília: Ministério da Saúde; 2011 [acesso 2017 dez 8]. Disponível em: http://bvsms.saude.gov.br/bvs/ publicacoes/plano_acoes_enfrent_dcnt_2011.pdf

11. Ministério da Saúde (Brasil). Secretaria de Atenção à Saúde. Diretrizes para o cuidado das pessoas com doenças crônicas nas redes de atenção à saúde e nas linhas de cuidado prioritárias. Brasília: Ministério da Saúde; 2013.

12. Ministério da Saúde (Brasil). Secretaria de Atenção à Saúde. Estratégias de promoção da alimentação saudável para o nível local: relatório da oficina de trabalho do I Seminário sobre Política Nacional de Promoção da Saúde. Brasília: Ministério da Saúde; 2007 [acesso 2015 abr 28]. Disponível em: www. nutricao.saude.gov.br/docs/geral/doc_tecnico_ pas_nivel_local.pdf 
13. Ministério da Saúde (Brasil). Secretaria de Atenção à Saúde. Estratégias para o cuidado da pessoa com doença crônica: obesidade. Brasília: Ministério da Saúde; 2014

14. Ministério da Saúde (Brasil). Secretaria de Gestão Estratégica e Participativa. II Caderno de educação popular em saúde. Brasília: Ministério da Saúde; 2014.

15. Mendes-Gonçalves RB. Tecnologia e organização social das práticas de saúde: características tecnológicas de processo de trabalho na rede estadual de Centros de Saúde de São Paulo. São Paulo: Hucitec; 1994.

16. Ministério do Desenvolvimento Social e Combate à Fome (Brasil). Secretaria Nacional de Segurança Alimentar e Nutricional. Marco de referência de educação alimentar e nutricional para as políticas públicas. Brasília: MDS; 2012.

17. Boog MCF. Contribuição da educação nutricional à construção da segurança alimentar. Saúde Rev. 2004;6(13):17-23.

18. Instituto Brasileiro de Geografia e Estatística. Pesquisa Nacional por Amostra de Domicílios: síntese de indicadores, 2009. Rio de Janeiro: IBGE; 2010.

19. Souza BFNJ, Marín-Léon L. Food insecurity among the elderly: Cross-sectional study with soup kitchen users. Rev Nutr. 2013;26(6):679-91. http://doi.org/10. 1590/S1415-52732013000600007

20. World Health Organization. Active ageing: A policy framework: A contribution of the World Health Organization to the Second United Nations World Assembly on Ageing. Madrid: WHO; 2002.

21. Organização Mundial da Saúde. Estratégia global em alimentação saudável, atividade física e saúde. Genebra: OMS; 2004.

22. Guimarães NG, Dutra ES, Ito MK, Carvalho KMB. Adesão a um programa de aconselhamento nutricional para adultos com excesso de peso e comorbidades. Rev Nutr. 2010;23(3):323-33. https://doi. org/10.1590/ S1415- 52732010000 300001

23. Bueno JM, Leal FC, Saquy LPL, Santos CB, Ribeiro RLP. Educação alimentar na obesidade: adesão e resultados antropométricos. Rev Nutr. 2011;24(4):575-84. https://doi.org/10.1590/S14 15-52732011000400006

24. Bevilaqua CA, Pelloso SM, Marcon SS. Stages of change of behavior in women on a multiprofessional program for treatment of obesity. Rev Latinoam Enfermagem. 2016;24:e2809. https:// doi.org/10.1590/1518-8345.0549.2809

25. Romeiro C, Nogueira JAD, Dutra ES, Carvalho $\mathrm{KMB}$. Redução de fatores de risco em adultos com excesso de peso usuários da estratégia saúde da família no Distrito Federal. Rev Nutr. 2013;26(6):659-68. https://doi.org/10.1590/S141 5-52732013000600005
26. Moreira P, Romualdo MCS, Amparo FC, Paiva C, Alves $\mathrm{R}$, Magnoni $\mathrm{D}$, et al. A educação nutricional em grupo e sua efetividade no tratamento de pacientes obesos. Rev Bras Obes Nutr Emagr. 2012;6(35):216-24.

27. Willett WC, Dietz WH, Colditz GA. Guidelines for healthy weight. N Eng J Med. 1999;341(6):427-34. https://doi.org/10.1056/NEJM199908053410607

28. Bombem KCM, Canella DS, Bandoni DH, Jaime PC. Impact of an educational intervention using email on diet quality. Nutr Food Sci. 2014;44(5):431-42. https://doi.org/10.1108/NFS-02-2013-0034

29. Deus RM, Mingoti SA, Jaime PC, Lopes ACS. Impacto de intervenção nutricional sobre o perfil alimentar e antropométrico de usuárias do Programa Academia da Saúde. Ciênc Saúde Coletiva. 2015;20(6):1937-46. https://doi.org/10.1590/14 13-81232015206.11882014

30. Malta DC, Santos MAS, Andrade SSCA, Oliveira TP, Stopa SR, Oliveira MM, et al. Tendência temporal dos indicadores de excesso de peso em adultos nas capitais brasileiras, 2006-2013. Ciênc Saúde Coletiva. 2016;21(4):1061-9. https://doi. org/10.1590/1413-81232015214.12292015

31. Ministério da Saúde (Brasil). Secretaria de Atenção à Saúde. Departamento de Atenção Básica. Política nacional de alimentação e nutrição. Brasília: Ministério da Saúde; 2013.

32. Ministérios do Desenvolvimento Social e Combate à Fome (Brasil). Câmara Interministerial de Segurança Alimentar e Nutricional. Estratégia intersetorial de prevenção e controle da obesidade: promovendo modos de vida e alimentação adequada e saudável para a população brasileira. Brasília: MDS; 2014.

33. Jaime PC, Silva ACF, Lima AMC, Bortolini GA. Ações de alimentação e nutrição na atenção básica: a experiência de organização no governo brasileiro. Rev Nutr. 2011;24(6):809-24. http:// dx.doi.org/10.1590/S1415-52732011000600002

34. Mendes AA, leker AS, Castro TF, Avelar A, Júnior NN. Multidisciplinary programs for obesity treatment in Brazil: A systematic review. Rev Nutr. 2016;29(6):867-84. https://doi.org/10.1590/1678-9 8652016000600011

35. Ministério da Saúde (Brasil). Secretaria de Atenção à Saúde. Departamento de Atenção Básica. Guia alimentar para a população brasileira. 2a ed. Brasília: Ministério da Saúde; 2014.

Received: June 23, 2017

Final version: December 19, 2017 Approved: January 31, 2018 